ISSN 0554-6397

UDK: 65.012.4:005.8

65.011:665.72.4

Preliminary communication

(PRETHODNO PRIOPĆENJE)

Received (Primljeno): 22.10.2015.

Sonja Brlečić Valčić, Ph.D.

E-mail: sonja.brlecic@gmail.com

Saipem SpA Croatian Branch, Alda Colonnela 2, 51000 Rijeka, Croatia

Mira Dimitrić, Ph.D.

E-mail: dimitric@efri.hr

University of Rijeka, Faculty of Economics, Ivana Filipovića 4, 51000 Rijeka, Croatia Martina Dalsaso, MBA

E-mail: martina.dalsaso@gmail.com

Lubanjski uspon 27, 51000 Rijeka, Croatia

\title{
Effective Project Management Tools for Modern Organizational Structures
}

\begin{abstract}
Project management is an important business operation factor for the majority of modern companies and public administrations. Therefore, its efficiency represents a challenge to all project teams and depends on the organizational, resource-based and technical complexities. Numerous studies are thus related to the project management efficiency and techniques of its application. In this context, modern business strategies oriented toward the creation and retention of value recognize the importance of the relationship between project management and company organization and management. In order for the system to completely satisfy the purpose, numerous factors should be brought in harmony, from working processes to systems of planning, reporting and analysis. In this paper, the advantages and disadvantages of existing systems for monitoring of project management within modern organizations are presented and the model for effective project management is accordingly proposed with the aim of eliminating disadvantages of business processes and planning procedures.
\end{abstract}

Key words: earned value management, work breakdown structure, cost breakdown structure, project management efficiency, oil and gas industry, oilfield service (OFS) companies 


\section{Introduction}

In general, projects are among the most important parts of companies. Therefore, a modern business organization is based on project management. One can notice that effective project management is a consequence of modern management practices which have significantly transformed organizations of today's companies. Projects have thus become a medium for monitoring and comparing of activities not only among departments but also among companies [11].

In addition, it should be noted that in project-oriented companies projects are the main part of value creation. Each individual project adds a certain value in terms of consumption and providing resources through the scope, quality, technical performance, features and functionalities [7].

Hence, the function of project management also changes, given the fact that in the past it was understood primarily as an organizational form of the operational dimension of general management in control of time-limited and targeted ventures [23].

Modern management thus tends to align and in some way identify the organizational business objectives with the project management process, which is determined from three standpoints, i.e. from the standpoint of objectives, processes for achieving objectives, and the level at which these processes are developed [19].

This is primarily related to the function of project management, which requires constant effort in monitoring the actual performance and forecasting the future performance of the remaining part of the project. As the crucial decisions in project management are often based on the expected future outcomes of the project, the project management efficiency mainly depends on the effective risk management. This mainly refers to the control of unexpected events, cash flow analysis, timely project financing, and the quality of predictive information based on actual performance data [12].

Within the modern project management, there are four different types of project values: desired, target, likely, and actual [7], that should be consistent with the same types of company's value creation. Thereby, project objectives, capabilities, risks and opportunities are evaluated in relation to the desired value. The target value is determined with regard to deadlines, budget and technical requirements of the project. As the final value of the project can be planned only with a certain probability, the category of likelihood value determines the uncertainty of objective achievements until the end of the project. All the above mentioned categories should be compared with the actual value of the project. Project management can be considered more successful at smaller deviations of listed categories from the actual value. In this context, modern studies emphasize three basic components that affect the development and implementation of projects, and eventually reflect on the organization of the overall business and financial results.

The first component relates to the arrangement and project forecasting, representing critical elements of proactive project monitoring to ensure its timely implementation [13]. The effective and efficient control is the second important component. It is 
necessary to achieve success in project management [21] regarding the avoidance of the risk of failure to fulfil the objectives, given the possibilities.

The third component is directly related to a continuous access to accurate information about the project. Namely, as complex projects generate a large amount of complex, specific and professionally-oriented information, often a lot of effort is put in to overcome the challenges of effective informing. Inefficient communication often leads to information chaos and causes problems in monitoring and implementation of projects [8].

The most commonly used system in project monitoring and management is the Earned Value Management (EVM) system, which represents an organized approach to integration and measurement of costs distribution and technical or business achievements, defined by project objectives. Unlike other project management techniques which are mainly focused on monitoring and control of project, EVM transcends this form and provides information that can more easily predict the future directions of the project [16]. It can be said that the Earned Value (EV) technique integrates the scope, arrangement and prices in one system, and measures the success of the project in terms of cash [15]. In order to be effective, the EVM system requires a detailed Work Breakdown Structure (WBS) elaboration and a close relationship between WBS system and the accounting supervision [10], i.e. a relationship with the Cost Breakdown Structure (CBS) system. However, as the EVM system is developed under certain assumptions, it is hard sometimes for project managers to follow the connection between the implementation and cost stages, depending on the comparison with planned values. Thus, recent studies suggest monitoring of the variability of deviations from planned values, so that project managers should be able to conclude whether the deviations from the planned values are in accordance with deviations from the variability of activities and, considering that, to take early corrective actions [1].

The problem, which is often emphasized in WBS-oriented models, arises because CBS does not contain spatial information, and WBS does not contain organizational information. It usually occurs because the hierarchical structure allows only one direction of the representation, leading to difficulties in representing various perspectives. A lower level of information is always dependent on a higher level of item. In addition, the hierarchical structure is inadequate in representing different levels of details, i.e. information units require several levels of details [8].

Therefore, in this paper, the features, advantages and disadvantages of the WBS and CBS as well as of the entire EVM system are presented. Moreover, financial results of project-oriented companies, indicating the conclusions about the performance of working processes are analysed. Based upon the theoretical basis and analyses, a conceptual model for effective monitoring of the working processes within the project management is proposed. 


\section{Planning, control and management of working processes and costs within the project management - advantages and disadvantages of existing systems}

In modern project management, one of the key elements of guidance and delivery of projects is WBS, which defines a logical division of work into manageable parts to facilitate planning, control and management of the project [18]. Therefore, it can be said that it regulates the hierarchical decomposition of work, which should be executed by the project team [22]. With the completion of one WBS structure for the project, the so-called "family tree" is created, whereby the overall structure of all activities is organized, defined and presented. These activities should be performed during the execution of the project in accord of the scope and deliverables, start and end dates, budget and identified responsible persons. Working tasks are defined in more detail with each following division of the structure. Although there is the established rule and the natural tendency that a more detailed analysis is more effective at the breakdown of the working structure, creating a WBS requires a certain amount of caution. Namely, the cost and business breakdown should be balanced, and the proper scope of the structure should be the one which reduces the degree of control over all the specific details of the project. This mainly refers to the large amount of information and details that need to be updated and monitored. Therefore, the optimal level of breakdown can be considered to be the sufficient one, but not detailed enough. A major role in achieving optimal WBS structures has an assessment based on the experience. The rule should be that the structure must be broken down in as much details as necessary to maintain control over the "working package" of tasks within the project.

Apart from the problem of achieving the optimal WBS, there are also problems concerning information management in the processes of monitoring and implementation of projects. Modern research in this context highlight some deficiencies such as: the lack of an integrated information system, fixed and one-way structure, sophisticated application techniques and the lack of proper validation procedure [8].

As the once defined work breakdown of the project is used to define the cost structure, the WBS and CBS should be related on the basis of the objective function, project stages, discipline and level of management.

Working tasks at all levels can be often divided into separate activities, which can be done by different departments. Hence, the costs should be allocated from the lowest level of WBS. One task can have several cost elements. When the tasks are assigned to costs, the project can be monitored in terms of actual and forecasted values of the project task.

The EV system defines the progress of the project and its budget by estimating costs that will incur during the project implementation. The key components of this process are:

- Basic cost and project schedule,

- Existing current expenses within project, and

- Reporting on the achievement of earned value. 
The cost and project schedule of basic activities refer to the actual schedule of tasks within the project, which is associated with the approved budget and the planned schedule of activities. In order to determine the earned value per finished work, it is therefore necessary to measure: the planned value, actual costs, cash flows and the assessment of the degree of completion. The question to which such a measure provides an answer is How much?, i.e. How much work needs to be done?; How much work has been done?; How much does the finished work cost?; What is the total budget for the project?; How much is expected for the total work to cost?

Although it appears that all the elements are hereby provided for the continuous application of the EVM system as mentioned before, since the system is defined in stable conditions, researches based on the monitoring of a number of completed projects indicate its many disadvantages.

Therefore, this indicates the need for a different approach, primarily by means of having participants of projects informed toward the purpose of efficient project management, and instead of asking How much?, the introduction of essential information units is proposed in order to achieve the desired integration structure, answering the questions: What?, When?, Where?, Who?, Why?, and How? [8]. In addition, there is already the previously mentioned optimization problem of WBS structure that is closely related to information management.

The proposal for monitoring the variability of deviations from planned values, necessary for project managers to be able to conclude whether the deviations from the planned values are in accordance with deviations from the variability of activities, was created precisely for the reason of efficient information management and thus, using these solutions, project managers are provided with a new approach to take early corrective measures in this manner [1].

As the conventional techniques of project management, such as EVM, are more focused on the time domain and the costs and less on quality, uncertainty, risks and opportunities, this indicates the need for the introduction of an integrated approach that takes into account all of the above [7].

Apart from these shortcomings of the EVM system, there is also a risk of incorrectly set objectives of the project which do not satisfy all the interested parties and which were observed from the long-time projects analysis. The aforementioned elements lead to a value gap between participants and interested parties [7], which significantly affects the value creation and retention of the companies.

With regard to the costs, project managers mainly rely on quantitative financial reports, usually on a monthly or quarterly basis. Due to the large amount of data, which are based on rough estimates of the percentage of the work completion degree, the information accuracy is not guaranteed. Furthermore, completed and invoiced costs are usually not integrated with information about the progress. Thus, the development of appropriate decision-support system is of great importance for the deployment of project management. This system should enable cost control and progress control, simplification or even automation of the process of data collection, automated functions of 
analysis, and should be applicable to all types of activities within the project [21]. Cost overruns due to delays can also be devastating for projects. Therefore, experts should be able to assess the effects on the project delays, and to quantify the costs or damages. Unfortunately, the effect of the delay in the context of time and costs is often difficult to understand and to measure with accuracy. Therefore, there are different methods for estimating the lost work productivity due to delays. However, conventional methods have a limited assumption that the rate of production activity is constant with time, i.e. production rate is linear. Sometimes, this assumption does not reflect the real situation on the progress of activities [2]. Hence, postponed activities should be identified and converted into the estimated effect of such delays, in terms of productivity [14].

Aspects that are absent in the standard EVM include the time value of money, payment delay of clients and subcontractors, cash flows in uncertain environment [17], and all of this is reflected on working processes and overall operations of the company as well as on financial results.

According to the opinion of project managers, the wide variety of corrective measures to eliminate disadvantages of the EV system can be divided into three different classes [20]:

- Reduction of the activity duration, known in literature as the activity system crash, which often results in higher costs,

- Parallel execution of related activities, known in literature as fast tracking,

- Re-baselining according to the main schedule in the event of significant changes in the scope, known as a change in the template of project network.

- Dynamic allocation refers to the integration of three important stages in the project's life cycle: the allocation basis, the analysis of risk schedule and the project control [20].

\section{Analysis of financial indicators of project-oriented companies for the assessment of working process performance}

Intercompany competitions tend companies to strive for excellence in the execution of tasks. Tendency for management excellence increases the importance of the functions of coordination, monitoring and control [11]. The effectiveness of the critical function of risk management, such as control of unexpected events, cash flow analysis, and timely project funding, profoundly depends on the quality of predictive informing based on actual performance data [12]. This is primarily manifested in monitoring costs and working tasks, but also in monitoring and relating costs and income with working capital and operating cash flows, in order to assess the performance of working processes and productivity.

Therefore, for the period from 2010 to 2013, the analysis of the financial indicators of 20 selected Oilfield Service (OFS) companies from the Oil \& Gas industry is performed in order to propose a model for better and more effective monitoring of 
working processes based on the WBS system [9]. The analysed companies were: Aecom Technology Corp, Fmc Technologies Inc, Wood Group (John) Plc, Kbr Inc, Subsea 7 $\mathrm{Sa}$, Petrofac Ltd, Sbm Offshore Nv, Foster Wheeler Ag, Oil States International Inc, Diamond Offshore Drilling, Oceaneering Intl Inc, Saipem SpA, Technip Sa, Transocean Ltd, Cameron International Corp, Atwood Oceanics Inc, C\&J Energy Services Inc, Cal Dive International Inc, Dril-Quip Inc and Ensco Plc-Cl A. Data for the analysis were collected from online available sources, primarily from [4].

OFS companies provide specialized equipment and skills needed for exploitation, drilling, testing, production, maintenance and recovery of oil and gas reservoirs, and for the design and construction of pipelines for transport of oil and gas. Namely, the research of oil fields and reserves and the production and transportation of oil and gas is a complex process, where each step in the chain of this process requires specific expertise and specialized technology. Furthermore, the discovery of oil and gas wells requires large and complex exploration, geological modelling, seismic studies and well extraction. In addition to the above mentioned services, companies of this sector also provide the equipment rental services required for the extraction or transportation of oil and gas [6]. Therefore, business operations of these companies are mainly related to the sector of exploitation and production of oil and gas.

The first indicator for the financial analysis beside revenues and costs is the Working Capital (WC). WC is a measure that is calculated by subtracting current liabilities from current assets, and in case of distortion, may significantly affect the firm's cash flow [5].

This measure indicates the efficiency of the company and short-term financial health, i.e. it indicates whether the company and projects need additional funding. Therefore, positive working capital means that the company is able to pay short-term obligations.

With the huge impact of price trends, one of the most influencing factors on working capital is certainly the development and expansion of capital investments. There are different methods of working capital management. They are built on different forms of business and operational models, relationships with customers, degree of vertical integration, the nature of the procurement and production [5]. On the basis of the analysed data, it can be concluded, as shown in Figure 1, that the trend of average working capital for the observed competitive companies recorded a decrease in the period from 2010 to 2011, and since then it has been increasing. Finally, in 2013 the trend reached a much higher values than those recorded in 2010. 


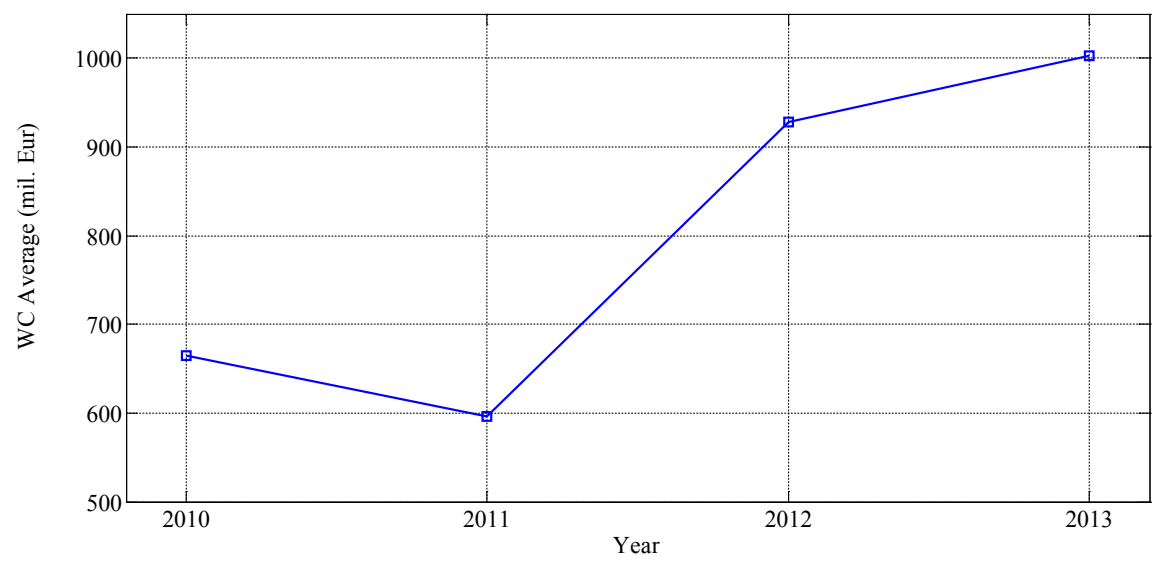

Figure 1. Average observed values of working capital (WC) for selected companies in the period 2010-2013

The comparison of working capital with the previous periods can lead to a conclusion on the efficiency of business operations and project management. This primarily refers to the comparison with similar competing companies.

The industry average of comparable working capital indicators of selected companies for the observed years is 1.0032. Thus the calculated average can be used for assessing the effectiveness of working processes and the project management efficiency for the observed company, and it can therefore be concluded that companies with the results above average are more efficient than the average and below average companies. For the same reason, working capital and operating revenue (OR) are being related, as well as working capital and operating expenses (OE).

A general control measure for the ratio of working capital and operating revenue is $25 \%$, if it is assumed that working capital should be $25 \%$ of total assets, and that the operating revenue is realized at the level of assets [3].

If the ratio of working capital and revenue is equal to the control measure, a company financially and accurately covers its operating cycle and uses its funds in an optimal manner. In the case where this ratio is higher than the control measure, a company financially covers its operating cycle and has a reserve of working capital which reduces the business risk, but on the other hand the use of funds is below optimum. The company financially does not cover its operating cycle and its liquidity is compromised, which increases the business risk if the ratio of working capital and revenues is less than the control measure. Furthermore, the negative ratio indicates severe financial problems and the threat of financial collapse [3].

The average of the net working capital over revenues for analysed companies in the observed period is $27.58 \%$. This, with the above mentioned, assumes that compa- 
nies with a higher amount than the average manage their working process in terms of efficiency better than those below the average.

Working capital in relation to operative expenses is also analysed, which also needs to be taken into account in the analysis of managing the working process in terms of efficiency. In the period from 2010 to 2013, its average is $44.88 \%$ (Table 1). Through the years, this ratio completely follows the trends of the previously analysed net working capital and operating revenue, which is shown in Figure 2. Operative cash flow (OCF) is also analysed for the same purpose and in the same manner.

The control measure of the ratio of operating cash flows and revenues (Cash ROS) is $10 \%$, because it is expected that the sales revenue earns the entire asset of the company in ten years in nominal (undiscounted) amount from free cash that remains to the OFS companies [3].

For analysed companies in the observed period, the average value of operating cash flows in relation to operating revenues is $15.79 \%$. In the same period, the average value of operating cash flows in relation to operative expenses is $27.82 \%$. The observed annual average values of analysed parameters for selected companies are presented in Table 1 and Figure 2.

Based on the performed analyses, it can be concluded that companies that achieve results above the control measure, especially those which achieve results above the industry average in the observed period, manage their working processes more efficiently.

Table 1. Observed average values of analysed parameters for selected companies

\begin{tabular}{|c|c|c|c|c|}
\hline & \multicolumn{4}{|c|}{ Year } \\
\hline & 2010 & 2011 & 2012 & 2013 \\
\hline WC Average & 665.0250 & 596.4100 & 928.4450 & 1002.5450 \\
\hline WC / Revenue & 0.3028 & 0.2403 & 0.2859 & 0.2744 \\
\hline WC / Cost & 0.5129 & 0.4097 & 0.4451 & 0.4279 \\
\hline OCF / Revenue & 0.1762 & 0.1649 & 0.1429 & 0.1476 \\
\hline OCF / Cost & 0.3220 & 0.2934 & 0.2480 & 0.2496 \\
\hline
\end{tabular}




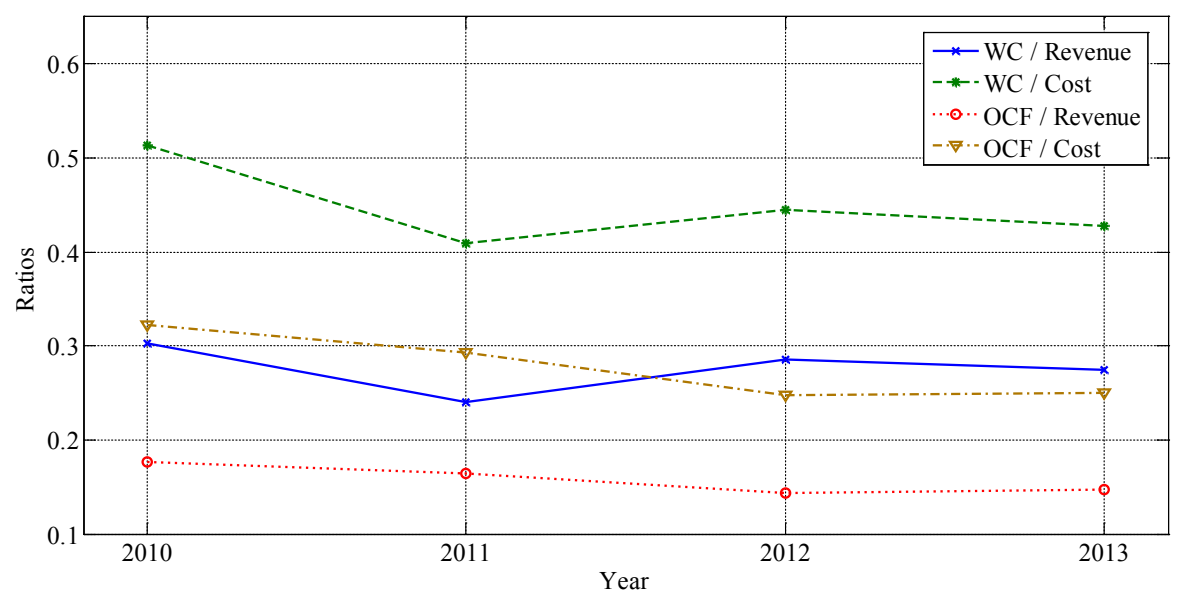

Figure 2. Visualization of observed average values of analysed parameters

\section{Model for effective monitoring of working processes within the project management}

Business development and monitoring, for the purpose of efficient management of costs and cash flows, primarily have to meet quality criteria, which depends on the purpose of business, time of realization and efficient control of costs and resources. Business organization set up in this way is oriented to the value creation, and it can be said that the project management is actually the value management. In order to ensure a quality value management, it is therefore necessary to monitor the relationship between business processes and cash flows.

For the earned value to be considered effective, given the quality level which in this context must be satisfied, it is necessary to ensure:

- Effective planning of the project tasks, resources, schedules and time domain of project implementation;

- $\quad$ Efficient setting of WBS and CBS structure;

- Efficient accounting system which is defined in a way that all accounting items are linked to the project number and defined WBS;

- Efficient management of working capital, operating cash flows and financing sources.

The earned value system needs to be constantly monitored, corrected and adjusted for the purpose of maximizing business quality in a way of:

- $\quad$ Providing reporting on all accounting items per project, according to the number and WBS structure, 
- Constantly monitoring the perennial results of similar companies in the environment with their comparison for the purpose of controlling business efficiency, in a way suggested in the analytical part of the paper,

- Attempting as early as possible to detect deficiencies in the working processes and business planning,

- Creating a knowledge database that will serve management in effective resource planning,

- Constantly adjusting and changing plans regarding actual events.

Proposed model for the development and monitoring of business processes, with the purpose of efficient management of costs and cash flows, is shown in Figure 3.

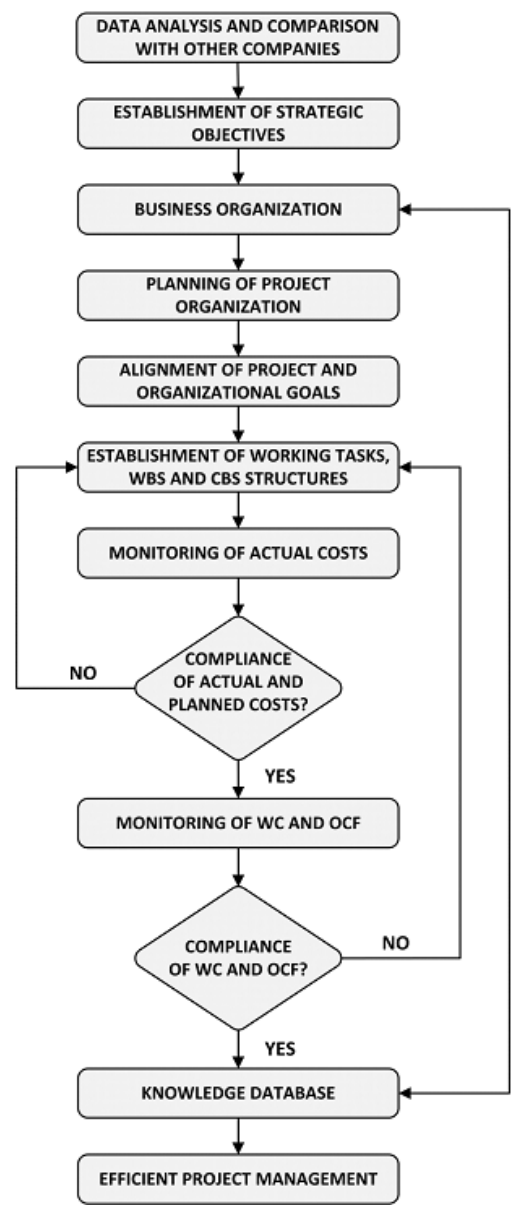

Figure 3. Conceptual model for the development and monitoring of business processes within efficient project management based on financial perspective 
Project management begins with planning of working tasks, costs and revenues. Therefore, the input to the model consists of data analysis and comparison with other companies. Analyses are related to the observation of operating expenses, revenues, working capital, operating cash flows, and the ratio of working capital and operating revenues, working capital and operative expenses, operative cash flows and revenues and operative cash flows and expenses, based on perennial period within the industry (competitive) environment. The comparisons are made on the basis of the control measure, and the perennial industry average.

On the basis of performed analyses, the strategic objectives are formed and accordingly the business organization, planning and organization of projects. Such analyses serve as a basis for contracting of new projects, primarily with the aim of defining the working tasks and cost of particular services, and for the decision on the manner of the revenue recognition (lump sum, reimbursable, cost plus, etc.).

After the defined contract with the client, the formation of working tasks and structures of the WBS and CBS begins. Analysis of deviations of planned and actual achievements is conducted periodically on a monthly, quarterly, semi-annual and annual basis. It is used to examine compliance between the actual and planed costs. In addition to compliance of costs and revenues, it is necessary to simultaneously monitor the working capital and operating cash flows in order to accurately identify deficiencies of operative business and the cause of deviations of the planned from the realized, and accordingly a better cost control. Based on the above, the knowledge base can be formed, as a prerequisite for effective planning in the future. Its purpose is the effective organization of business, and therefore it must be constantly enhanced, and on its basis the business organization needs to be changed for the purpose of efficiency and value creation.

\section{Conclusion}

Effective project management is one of the most important factors of almost all modern companies, including public administrations. Hence, the organization and management is being increasingly associated with project management. Additionally, it is being recognized that for project management, and therefore for the organization and management of companies, identification of factors that affect working processes is very important. This primarily refers to the quality, uncertainty, risks and opportunities, in order to achieve efficient business.

For this purpose, in the system of earned values, categories of planning, operative business, comparison of planned and realized and financing should be harmonized. In order to achieve this, the planning of project tasks, resources, schedules and time must be based on optimally set WBS and CBS, effective accounting system as well as awareness of the need for the working capital management efficiency, operating cash flow sufficiency and quality of financing sources. 
Constant monitoring and analysis of working capital, cash flow and ratio of working capital and operating revenues, as well as operative cash flows and operative revenues, compared to the control measure and perennial industrial average, leads to the conclusion about the optimal use of funds, but also about working capital reserves and, in this respect, business risks.

Effective reporting per project, results analysis and comparisons with other companies, detecting of deficiencies, creating the database and a constant plan updating, ensure the efficiency of the earned value system.

In this paper, a model for the development and monitoring of business processes in the EVM system, which is based on these assumptions, is proposed. Using such models can significantly contribute to the improvement of operative business of companies. Limitations of the model are related to the lack of information that can occur in data analysis and the forming of a knowledge database.

\section{Acknowledgment}

This work has been supported by the Croatian Science Foundation under the project 6558 Business and Personal Insolvency: The Ways to Overcome Excessive Indebtedness and by the University of Rijeka under the project number 13.02.1.2.09.

\section{References}

1. Acebes, F. Pajares, J., Galan, J. M., \& Lopez-Paredes, A. (2014). A new approach for project control under uncertainty. Going back to the basics. International Journal of Project Management, 32(3), 423-434.

2. Arditi, D., Tokdemir, O. B., \& Suh, K. (2001). Effect of learning on line-of-balance scheduling, International Journal of Project Management, 19(5), 265-277.

3. Belak, V. (2014). Business Excellence Analysis. Zagreb, Croatia: RRiF-plus. (in Croatian)

4. Bloomberg Business (2015). [Online] Available: http://www.bloomberg.com (May, 2015)

5. Brlečić Valčić, S., Katunar, J., \& Katunar, H. (2015). Using financial parameters to identify elements of creating and retaining maritime firms' stakeholder value within the value in use concept. Pomorstvo: Scientific Journal of Maritime Research, 29(1), 16-22.

6. Brlečić Valčić, S. (2014). Modern approach to business valuation of oil and gas companies based on computational intelligence. Doctoral Dissertation. Rijeka, Croatia: University of Rijeka, Faculty of Economics. (in Croatian)

7. Browning, T. R. (2014). A Quantitative Framework for Managing Project Value, Risk, and Opportunity. IEEE Transactions on Engineering Management, 61(4), 583-598.

8. Cho, D., Russell, J., \& Choi, J. (2013). Database Framework for Cost, Schedule, and Performance Data Integration. Journal of Computing in Civil Engineering, 27(6), 719-731.

9. Dalsaso, M. (2015). The development of operational and business analysis of costs according to the structure of the OFS sector of oil and gas industry. Master Thesis. Rijeka, Croatia: University of Rijeka, Faculty of Economics. (in Croatian)

10. Haugan, G. T. (2002). Effective Work Breakdown Structures. Vienna, VA: Managment Concepts.

11. Hazır, Ö. (2015). A review of analytical models, approaches and decision support tools in project monitoring and control. International Journal of Project Management, 33(4), 808-815.

12. Kim, B.-C. (2015). Integrating Risk Assessment and Actual Performance for Probabilistic Project Cost Forecasting: A Second Moment Bayesian Model. IEEE Transactions on Engineering Management, 62(2), 158-170. 
13. Kim, B., \& Kim, H. (2014). Sensitivity of Earned Value Schedule Forecasting to S-Curve Patterns. Journal of Construction Engineering and Management, 140(7), 1-11.

14. Lee, J.-S. (2015). Calculating cumulative inefficiency using earned value management in construction projects. Canadian Journal of Civil Engineering, 42(4), 222-232.

15. Marzouk, M., \& Hisham, M. (2014). Implementing Earned Value Management using Bridge Information Modeling. KSCE Journal of Civil Engineering, 18(5), 1302-1313.

16. Norman, E. S., Brotherton, S. A., \& Fried, R. T. (2008). Work Breakdown Structures: The Foundation for Project Managment Excellence. New Jersey: John Wiley \& Sons.

17. Salari, M., Bagherpour, M., \& Kamyabniya, A. (2014). Fuzzy extended earned value management: A novel perspective. Journal of Intelligent \& Fuzzy Systems, 27(3), 1393-1406.

18. Special Publication SP-2010-3404: NASA Work Breakdown Structure (WBS) Handbook, January 2010. [Online] Available: http://www.sti.nasa.gov (May, 2015)

19. Turner, J. R. (2009). The handbook of project-based management - Leading Strategic Change in Organizations. (3rd ed.). London, UK: McGraw-Hill.

20. Vanhoucke, M. (2012). Measuring the efficiency of project control using fictitious and empirical project data. International Journal of Project Management, 30(2), 252-263.

21. Wang, X., Yung, P., Luo, H., \& Truijens, M. (2014). An innovative method for project control in LNG project through 5D CAD: A case study. Automation in Construction, 45, 126-135.

22. WBS (2015). Work Breakdown Structure. [Online] Available: http://www.workbreakdownstructure. com (May, 2015)

23. Zekić, Z. (2010). Project management - Managing development changes. Rijeka, Croatia: University of Rijeka, Faculty of Economics \& Conefing Group. (in Croatian) 


\title{
Alati učinkovitog projektnog menadžmenta za suvremene organizacijske strukture
}

\begin{abstract}
Sažetak
Projektni menadžment jest važan čimbenik poslovanja većine današnjih poduzeća i javnih uprava. Stoga je njegova učinkovitost izazov svih projektnih timova, a ovisi o organizacijskim, resursnim i tehničkim kompleksnostima. Mnogobrojna istraživanja vezana su tako za efikasnost projektnog menadžmenta i tehnike njegove primjene. Moderne strategije poslovanja, okrenute stvaranju i očuvanju vrijednosti, prepoznaju značenje povezanosti projektnog menadžmenta s organizacijom i menadžmentom poduzeća. Kako bi takav sustav u potpunosti zadovoljio tu svrhu, potrebno je uskladiti brojne čimbenike, od radnih procesa do sustava planiranja, izvještavanja i analize. U radu se izlažu prednosti i nedostaci postojećih sustava za praćenje projektnog menadžmenta u sklopu modernih organizacija te se predlaže model za učinkovito upravljanje projektima, u svrhu otklanjanja nedostataka poslovnih procesa i nedostataka postupka planiranja.
\end{abstract}

Ključne riječi: projektni menadžment, EVM, WBS, CBS, efikasnost poslovnih procesa, naftno-plinska industrija, naftno-plinska servisna poduzeća (OFS) 